\title{
Management of Bilateral Complicated Cataract in Convalescent Stage of Vogt- Koyanagi-Harada Syndrome
}

\author{
Faradina R. Quamila ${ }^{1}$, Ovi Sofia ${ }^{1}$, T.Budi Sulistya ${ }^{1}$ \\ ${ }^{1}$ Department of Ophthalmology, Faculty Of Medicine, Universitas Brawijaya, \\ Dr. Saiful Anwar General Hospital, Malang, Indonesia \\ E-mail:dr.ovisofia@ub.ac.id
}

\begin{abstract}
ABSTRAK
Pendahuluan: Insiden katarak komplikata pada sindrom VKH di Jepang adalah 35\% dan 40\% di Amerika Serikat. Operasi ekstraksi katarak bertujuan untuk mengevaluasi segmen posterior dan pada beberapa kasus dapat meningkatkan tajam penglihatan.

Tujuan: Melaporkan pendekatan diagnostik dan keberhasilan penatalaksanaan komplikasi katarak bilateral pada sindrom Vogt-Koyanagi-Harada fase konvalesen.

Laporan Kasus: Seorang wanita berusia 24 tahun datang ke poliklinik rawat jalan RSUD Dr. Saiful Anwar Malang dengan keluhan penglihatan kabur pada kedua mata yang memburuk 2 bulan sebelum kunjungan, disertai sakit kepala, mual, demam, rambut rontok, dan pemutihan rambut wajah mulai 1 bulan. Pemeriksaan umum menunjukkan alopecia dan poliosis. Tajam penglihatan pada kedua mata adalah 1/300. Pemeriksaan segmen anterior menunjukkan KP coklat polimorfik, flare 4+ dan sel 4+, seklusio pupil, dan katarak pada kedua mata. Pada pemeriksaan USG didapatkan vitritis dan penebalan koroid. Tidak didapatkan kelainan pada pemeriksaan laboratorium. Pasien didiagnosis dengan sindrom Vogt-Koyanagi-Harada fase konvalesen dengan komplikasi katarak dan telah di terapi dengan kombinasi kortikosteroid oral dan azathioprine. Sinekiolisis dan ekstraksi katarak mata kiri dilakukan di bawah perlindungan kortikosteroid oral dan injeksi triamcinolone subtenon posterior. Didapatkan peningkatan tajam penglihatan dan tidak didapatkan rekurensi infeksi pasca operasi.

Kesimpulan: Terdapat perbaikan visus mata kiri yang signifikan setelah operasi ekstraksi katarak dengan kontrol inflamasi yang baik sebelum operasi. Tidak ada kekambuhan uveitis selama 6 bulan follow up.
\end{abstract}

Kata kunci: sindrom Vogt-Koyanagi-Harada, katarak komplikata, panuveitis non infeksius, steroid, imunomodulator, fase konvalesen.

\section{ABSTRACT}

Introduction: The incidence of complicated cataract in VKH syndrome in Japan is $35 \%$ and $40 \%$ in US. Cataract extraction surgery is advisable for evaluating posterior segment and improving visual acuity. This study is reporting management of bilateral complicated cataract in Vogt-KoyanagiHarada syndrome convalescent stage under corticosteroid coverage.

Purpose: To report the diagnostic approach and successful management of bilateral complicated cataract in convalescent stage of Vogt-Koyanagi-Harada syndrome 
Case Presentation: A 24-year old woman came to the outpatient clinic of Dr. Saiful Anwar Hospital Malang complaining of blurred vision on both eyes which worsen 2 months prior to visit. It was accompanied with headache, nausea, fever, hair loss, and facial hair whitening started 1 month afterwards. General examination showed alopecia and poliosis. The visual acuity of both eyes were hand motion. Anterior segment examination showed polymorphic old KPs, 4+ flare and 4+ cells, secluded pupil, and cataract in both eyes. Vitritis and choroidal thickening were noted from ultrasound examination. Laboratory examination results were within normal limit. She was diagnosed with VogtKoyanagi-Harada syndrome convalescent stage with complicated cataract and had been treated with combination of oral corticosteroid and azathioprine. Synechiolysis and cataract extraction of left eye were performed under oral corticosteroid and posterior subtenon triamcinolone injection coverage. There was improvement of visual acuity and controlled inflammation postoperatively.

Conclusion: Significant visual improvement of left eye was shown after cataract extraction surgery under adequate inflammation control preoperatively. There was no relaps of uveitis during 6 months follow up.

Keyword: Vogt-Koyanagi-Harada syndrome, complicated cataract, non-infectious panuveitis, steroid, immunomodulator, convalescent stage.

\section{INTRODUCTION}

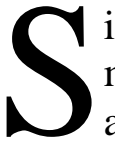
indrom Vogt-Koyanagi-Harada merupakan penyakit multisistem autoimun dengan tanda panuveitis granulomatosa kronik, bilateral, dan manifestasi ekstraokular pada sistem saraf pusat, sistem pendengaran, dan sistem integumen. ${ }^{1,2}$ Penyebab pasti penyakit VogtKoyanagi-Harada (VKH) masih tidak diketahui, tetapi kemungkinan besar peran dari autoimunitas yang dimediasi oleh Tlimfosit yang diarahkan melawan melanosit yang dimiliki oleh semua organ yang terlibat. ${ }^{3}$ Penyakit ini banyak diderita oleh ras kulit berwarna, khususnya di Asia dan sering pada wanita berusia antara $20-50$ tahun. Penyakit ini pertama kali dijelaskan oleh Vogt pada tahun 1906 pada pasien dengan poliosis yang disertai dengan uveitis bilateral, vitiligo, alopesia dan diskaousia. Kasus yang sama kemudian dilaporkan oleh Koyanagi pada tahun 1929, dan Harada pada tahun 1926 melaporkan pasien dengan uveitis, ablasio retina eksudatif dengan pleositosis pada cairan serebrospinal. ${ }^{2,4} \mathrm{Di}$ Indonesia, laporan kasus yang telah dipublikasikan antara lain pasien berusia 15 tahun pada tahun 1998 di Yogyakarta ${ }^{5}$ dan pasien laki-laki berusia 8 tahun pada tahun 2011 di Rumah Sakit Hasan Sadikin Bandung. ${ }^{4}$ Moorthy et al telah melaporkan katarak pada $40 \%$ pasien mereka di Amerika
Serikat. ${ }^{6}$ Terjadinya katarak pada uveitis dapat disebabkan oleh peradangan kronis dan efek dari pengobatan kortikosteroid jangka panjang. Peradangan intraokular menyebabkan tingginya tingkat sitokin proinflamasi seperti TGF-b dalam humor aqueous dan vitreous. Sel ini dapat melewati kapsul lensa dan menginduksi transisi mesenchymal dari epitel lensa anterior. Hal ini yang menyebabkan perubahan pada epitel dan struktur dari lensa. ${ }^{7}$

Gejala yang dikeluhkan oleh pasien dengan VKH sangat bergantung pada stadium penyakit. Stadium penyakit ini dibagi atas empat fase klinis yaitu prodormal, uveitis akut, konvalesen dan kronis-rekuren. ${ }^{8}$ Fase prodromal, ditandai oleh manifestasi neurologis dan pendengaran; fase uveitis akut, ditandai dengan choroiditis difus, yang dapat bermanifestasi sebagai ablasio retina eksudatif di antara papil dan makula juga papilitis, dengan atau tanpa tanda-tanda klinis peradangan intraokular; fase konvalesen, ditandai dengan perkembangan variabel depigmentasi fundus (sunset glow fundus) dan limbus (Sugiura's sign), serta poliosis, vitiligo, dan alopecia; fase rekuren, dengan iridosiklitis, yang berulang, kronis, atau keduanya. ${ }^{9}$ Kehilangan penglihatan permanen, mulai dari ringan hingga berat, adalah umum dan biasanya merupakan 
akibat dari komplikasi yang timbul dari penyakit dan atau pengobatan yang tidak teratur, termasuk katarak, glaukoma, membran neovaskuler koroidal, dan fibrosis subretinal. $^{2,3}$ Prinsip terapi penyakit VKH syndrome adalah sesuai dengan fase yang terjadi, pemberian kortikosteroid sistemik dosis $1-1.5 \mathrm{mg} / \mathrm{KgBB} / \mathrm{hari}$ dan pemberian azathioprine sebagai first line immunodulator fase prodromal dan akut uveitis, ${ }^{10}$ sedangkan pada fase kronisrekuren dengan komplikasi seperti katarak, operasi ekstraksi katarak dapat meningkatkan tajam penglihatan. ${ }^{3}$

Berikut akan dilaporkan suatu kasus seorang wanita berusia 24 tahun dengan Vogt-Koyanagi-Harada Syndrome fase konvalesen disertai komplikasi berupa katarak komplikata bilateral, seklusio pupil dan penatalaksanaannya.

\section{LAPORAN KASUS}

Pada tanggal 26 Juli 2018, seorang wanita usia 24 tahun datang ke Poliklinik Mata RS dr. Saiful Anwar Malang dengan keluhan kedua mata kabur perlahan sejak 2 bulan yang lalu. Mata terasa silau apabila terkena sinar dan tidak didapatkan keluhan mata lain seperti nyeri, mata berair, sekret. Tidak didapatkan riwayat sakit mata sebelumnya. Tidak didapatkan riwayat trauma dan juga operasi mata sebelumnya. Riwayat penurunan pendengaran dan berdengung dirasakan sejak 2 bulan yang lalu sebelum pasien datang ke rumah sakit. Terdapat keluhan lain seperti nyeri kepala, mual, demam, rambut rontok juga alis dan rambut mulai memutih sejak 1 bulan terakhir. Tidak didapatkan batuk lama, gigi berlubang, sariawan, dan nyeri sendi. Tidak didapatkan riwayat penyakit sistemik seperti Diabetes Mellitus, Hipertensi, dan lainnya. Riwayat pengobatan, diberi tetes mata golongan beta blocker $0.5 \% 2 \times 1$ tetes ODS dan acetazolamide oral $3 \times 250 \mathrm{mg}$. Riwayat keluarga tidak ada yang memiliki riwayat sakit yang sama.

Dari pemeriksaan status umum didapatkan keadaan umum compos mentis, GCS 456, tekanan darah 120/80 mmHg. Status motorik dan sensorik dalam batas normal. Pada pemeriksaan fisik didapatkan rambut rontok dan alopecia, tidak didapatkan vitiligo, dan didapatkan gangguan pendengaran, pada pemeriksaan oftalmologis didapatkan tajam penglihatan mata kanan dan kiri 1/300 didapatkan poliosis pada kedua mata. Pemeriksaan segmen anterior tidak didapatkan hiperemi pada konjungtiva, didapatkan keratic presipitat berwarna coklat berbentuk polymorfik pada kedua mata, tidak didapatkan Sugiura's sign, bilik mata depan dangkal, Van Herick II, terdapat flare 4+ dan cell 4+, pada pupil terdapat seklusio pupil dan kekeruhan pada lensa. Tekanan intraokuli $14,6 \mathrm{mmHg}$ pada kedua mata.

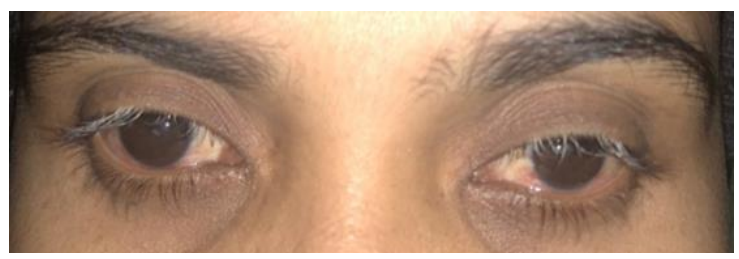

(a)

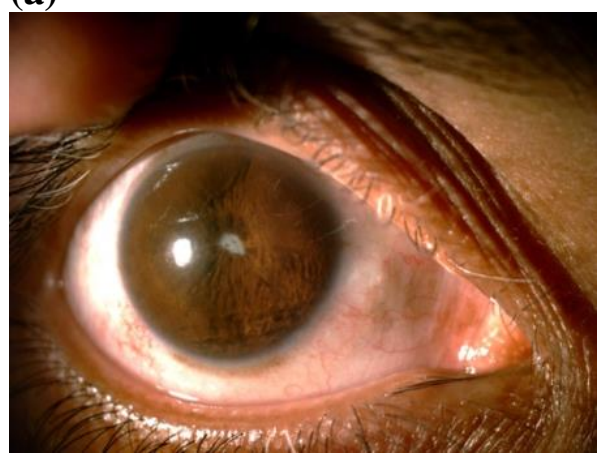

(b)

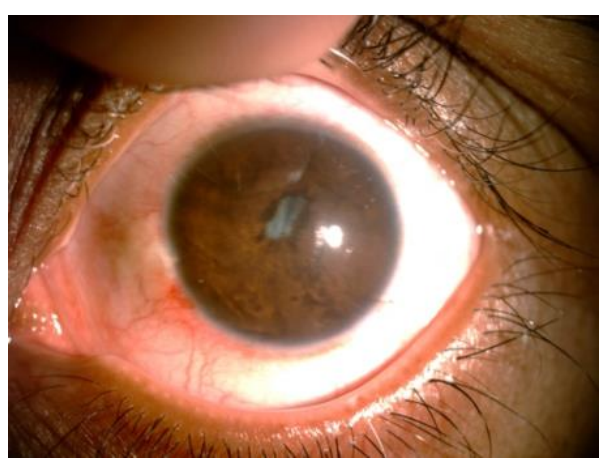

(c)

Gambar 1. Foto segmen anterior. Tampak poliosis pada kedua mata. (a) foto kedua mata, (b) mata kanan, (c) mata kiri terdapat iris bombans, sinekia posterior, seklusio pupil, dan lensa keruh. 
Pada pemeriksaan segmen posterior pada kedua mata tidak didapatkan reflex fundus dan detail sulit dievaluasi. Dari pemeriksaan USG didapatkan gambaran vitritis dan penebalan koroid pada mata kanan dan kiri.

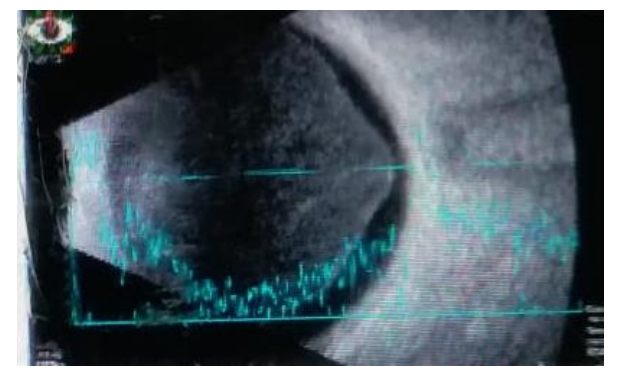

(a)

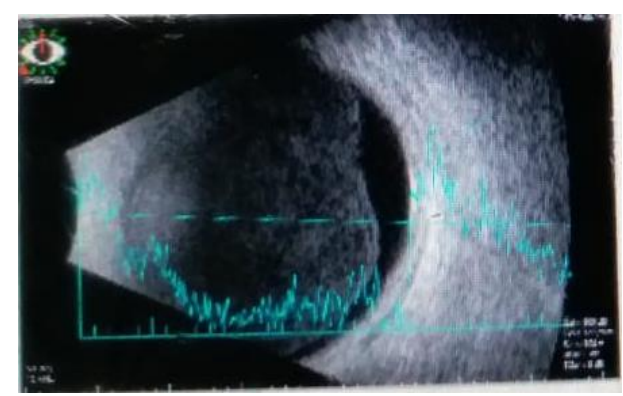

(b)

Gambar 1. Hasil pemeriksaan USG. Tampak adanya kekeruhan pada vitreous media dan posterior dengan gambaran low to medium spike, juga didapatkan penebalan koroid pada kedua mata (tanda panah merah). (a) mata kanan, (b) mata kiri.

Dari hasil pemeriksaan penunjang laboratorium, foto thorax dan mantoux test didapatkan hasil yang normal dan tidak didapatkan hasil yang mendukung adanya suatu infeksi.

Pasien didiagnosa ODS katarak komplikata dt Vogt-Koyanagi Harada Syndome fase konvalescence. Pasien direncanakan pemberian kortikosteroid sistemik dengan dosis $1 \mathrm{mg} / \mathrm{Kgbb} / \mathrm{hari}$ (45mg-0-0) dan azathioprine $1-2.5$ $\mathrm{mg} / \mathrm{kgbb} /$ hari $(2 \times 50 \mathrm{mg} / \mathrm{hari})$. Obat tetes topikal diberikan betamethason tetes 6 kali sehari dan sikloplegik sulfas atropin tetes mata 3 kali sehari pada kedua mata. Pasien tidak kontrol selama 1 bulan dan mengulang pemberian prednisone, yang selanjutnya dosis prednisone diturunkan perlahan.
Setelah 1 bulan
kortikosteroid, peningkatan tekanan intraokuli yang awalnya 14,6 mmhg menjadi 43,4 mmhg pada kedua mata. Kondisi segmen anterior masih sama dengan kondisi sebelumnya namun didapatkan penurunan grading flare dan cell menjadi negatif. Pasien diberikan acetazolamide 3 × $250 \mathrm{mg}$ dan tetes mata beta blocker $2 \times 1$ mata kanan dan kiri.

Pada bulan ke 5 pengobatan pasien direncanakan operasi ekstraksi katarak pada mata kiri. Untuk persiapan operasi dilakukan pemberian perlindungan steroid dosis 40mg-0-0 H-3 pre operasi dan injeksi triamcinolone acetonide $40 \mathrm{mg} / \mathrm{ml}$ subtenon posterior pada $\mathrm{H}-7$ pre operasi.

Kondisi segmen anterior $\mathrm{H}+2$ minggu pasca operasi didapatkan tajam penglihatan 6/75 ph 6/38, hiperemi konjungtiva minimal, keratic presipitat berwarna coklat, terdapat jahitan berjumlah 1, edema kornea minimal, tidak didapatkan flare dan cell, pupil bulat diameter $4 \mathrm{~mm}$, pada lensa didapatkan IOL on place dan didapatkan pigmen iris, tekanan intraokuli dalam batas normal.

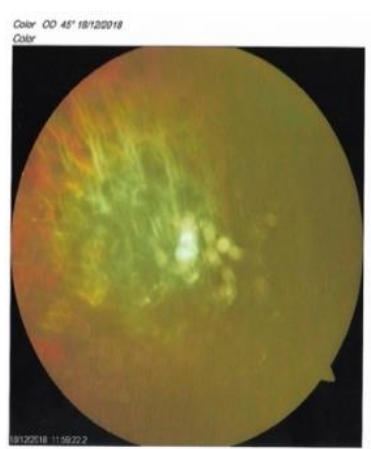

(a)

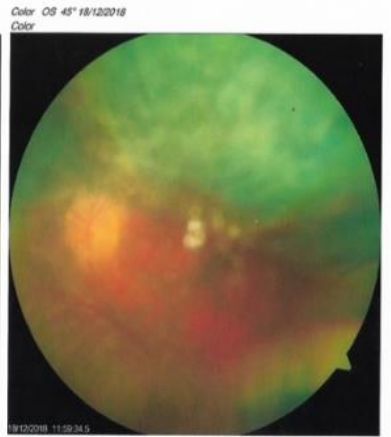

(b)
Gambar 3. Foto fundus. Follow up 2 minggu pasca operasi. (a) Mata kanan, (b) Mata kiri, pada kedua mata detail tidak dapat di evaluasi dikarenakan vitritis.

Pasien masih diberikan terapi oral azathioprine 2 x $50 \mathrm{mg}$ dan kortikosteroid 20mg-0-0. Namun pasien tidak kontrol selama 1,5 bulan. Pada kontrol terakhir $\mathrm{H}+4$ bulan pasca operasi didapatkan tajam penglihatan mata kiri pasien membaik menjadi $6 / 38$ ph $6 / 30$ namun visus mata 
kanan menjadi LP (-), dan didapatkan vitreous cell grade $4(+)$ pada pemeriksaan segmen posterior.

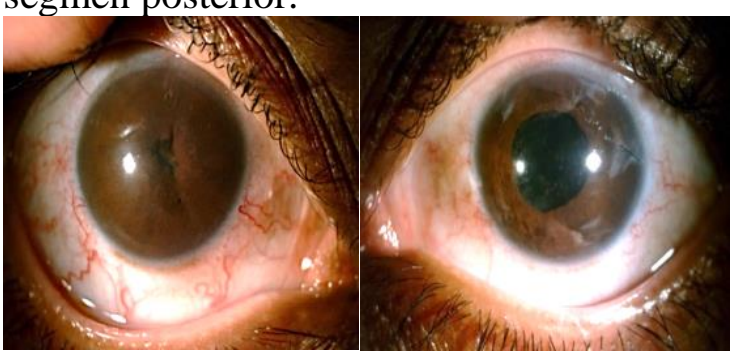

(a)

(b)

Gambar 4. Foto Segmen anterior. Foto follow up 4 bulan pasca operasi katarak mata kiri (a) mata kanan, didapatkan seklusio pupil memberat, (b) mata kiri, tidak didapatkan hiperemi pada konjungtiva, didapatkan keratic presipitat berwarna coklat, pupil bulat,dan pada lensa IOL on place.

\section{PEMBAHASAN}

Kriteria diagnosa $\mathrm{VKH}$ dapat ditegakkan berdasarkan anamnesa, gejala manifestasi intra dan ekstra okular yang khas serta pemeriksaan penunjang. Disamping gambaran klinis dan kriteria diagnosis yang ada, hal yang penting dalam menegakkan diagnosis VKH pada pasien ini yaitu kelainan bilateral, tidak ada riwayat trauma dan tidak terbukti adanya penyakit lain pada mata serta penyakit sistemik.

Berikut adalah tabel yang mengacu pada The First international Workshop on VKH Disease.

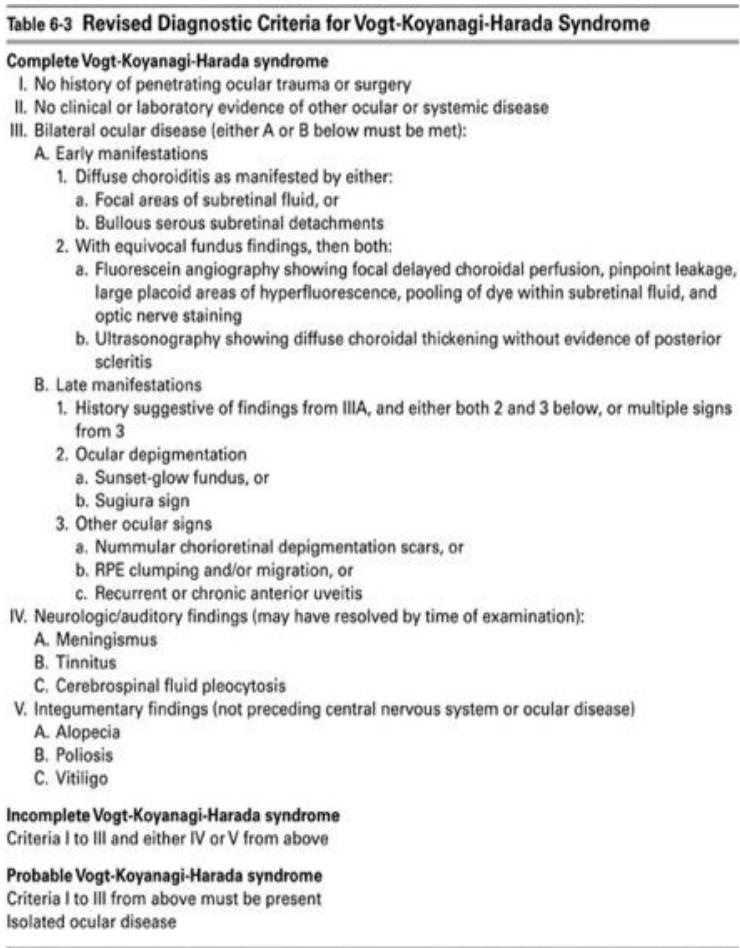

Adapted from Read RW, Holland GN, Rao NA, et al. Revised diagnostic criteria for Vogt:-Kovanagi.Harad disease: report of an international committee on nomendature. Am J Ophthalmol. 2001;131(5):647-652.

Tabel 1. Tabel kriteria diagnosa VogtKoyanagi-Harada pada The First International Workshop on VKH Disease 3

Pada pasien ini memenuhi kriteria suatu VKH komplit yang ditandai dengan kelainan mata bilateral dan terdapat gejala neurologik sebelumnya seperti demam, sakit kepala, mual, tinnitus dan terdapat gejala integumentary seperti alopecia, poliosis namun tidak didapatkan vitiligo. ${ }^{3}$ Stadium konvalesen merupakan stadium pertengahan dari VKH yang ditandai dengan terlibatnya gejala di luar mata seperti alopecia, vitiligo, poliosis dan tinnitus. Gejala neurologi bisa muncul namun jarang. Tinnitus muncul sekitar $30 \%$ pasien dan membaik 2-3 bulan. Hal ini sesuai dengan anamnesa keluhan yang disampaikan oleh pasien.

Berdasarkan literatur penurunan penglihatan pada kedua mata muncul pada stadium uveitis akut 1-2 hari sesudah stadium prodormal. Dan gejala lainnya muncul beberapa minggu setelahnya yaitu memasuki stadium konvalesen. Pada stadium ini juga ditemui adanya keratik presipitat berwarna coklat. Pada pemeriksann USG didapatkan vitritis. Tekanan intra okular (TIO) pada pasien ini 
awalnya normal namun setelah 2 bulan kontrol didapatkan peningkatan TIO akibat terjadinya blok pupil.

Pemeriksaan segmen posterior pada mata kanan sulit di evaluasi dikarenakan sinekia posterior $360^{\circ}$ dan terdapatnya katarak, sedangkan pada mata kiri didapatkan kekeruhan pada vitreous dikarenakan vitritis. Dari pemeriksaan USG didapatkan gambaran vitritis dan choroidal thickening pada kedua mata. Pada pasien ini hasil pemeriksaan penunjang laboratorium didapatkan dalam batas normal, termasuk fungsi ginjal dan fungsi hepar dan tidak ada tanda-tanda suatu infeksi.

Pasien diterapi menggunakan steroid dosis imunosupressan prednison dosis $1 \mathrm{mg} / \mathrm{KgBB} /$ hari yang kemudian diturunkan perlahan dan bertahap dikombinasi dengan imunomodulator azathioprine tablet dosis 2 x 50 $\mathrm{mg} / \mathrm{KgBB} /$ hari. Pasien juga mendapatkan terapi steroid topikal dan siklopegik. Berdasarkan literatur terapi utama dari VKH adalah kortikosteroid prednison 1$1,5 \mathrm{mg} / \mathrm{kgBB}$ per hari. Kortikosteroid topikal merupakan terapi tambahan pada VKH yang diberikan bila terdapat uveitis anterior. ${ }^{11,12}$ Sikloplegik homatropin juga harus diberikan untuk mencegah terjadinya sinekia posterior. Imunomodulator golongan antimetabolit seperti azathioprine merupakan pilihan pertama (first line) yang digunakan untuk terapi VKH. ${ }^{13}$

Pada pasien ini sudah ditemukan tanda-tanda komplikasi seperti katarak, dimana menurut Rao, et. Al katarak adalah komplikasi terbanyak (40\%) yang terjadi pada pasien VKH fase konvalesen atau kronik-berulang. ${ }^{3,14}$ Sehingga penanganan utama adalah dilakukan operasi ekstraksi katarak dan sinekiolisis dengan pemasangan lensa tanam yang bertujuan untuk memperbaiki tajam penglihatan dan mengevaluasi kondisi segmen posterior. ${ }^{13,15}$ Sebelum operasi dilakukan perlindungan steroid dengan prednison dan injeksi triamcinolone acetonide. ${ }^{11}$

Follow up pemeriksaan tajam penglihatan, segmen anterior dan segmen posterior dilakukan selama 6 bulan untuk memonitor respon terapi dan tanda-tanda rekurensi. Pada pasien ini respon yang baik ditunjukkan pada bulan ke 2 setelah pemberian kortikosteroid oral dengan imunomodulator dan untuk tajam penglihatan menunjukkan perbaikan dari hari pertama pasca operasi katarak dan semakin baik sampai 3 bulan setelahnya yaitu menjadi 6/38 S -1.00 menjadi 6/30 ph (-). Setelah pasien tidak kontrol dan lepas pengobatan selama 1,5 bulan mengakibatkan relaps dan penurunan tajam penglihatan pada mata kiri menjadi LP (-).

Berdasarkan literatur prognosa yang baik didapatkan dengan terapi yang agresif, deteksi dini, dan tapering oral steroid dengan perlahan serta penggunaan imunomodulator. Faktor lain prognosis VKH juga bergantung pada durasi dan angka episode rekurensi peradangan. ${ }^{9,16}$

\section{DAFTAR PUSTAKA}

1. Sheriff F, Narayanan NS, Huttner AJ, Baehring JM. Vogt-Koyanagi-Harada syndrome: A novel case and brief review of focal neurologic presentations. Neurology-Neuroimmunology Neuroinflammation. 2014;1(4):e49.

2. Baltmr A, Lightman S, Tomkins-Netzer O. Vogt-Koyanagi-Harada syndromecurrent perspectives. Clinical ophthalmology (Auckland, NZ). 2016;10:2345.

3. Read RW, Rechodouni A, Butani N, Johnston R, LaBree LD, Smith RE, et al. Complications and prognostic factors in Vogt-Koyanagi-Harada disease. American journal of ophthalmology. 2001;131(5):599-606.

4. Setiabudiawan B, Karfiati F, Ghrahani R, Sapartini G, Sahril I. Vogt-KoyanagiHarada disease in an 8-year-old boy. Asia Pacific Allergy. 2011;1(2):98-103.

5. Suhardjo S. Vogt-Koyanagi-Harada Syndrome: A case report. Journal of the Medical Sciences (Berkala ilmu Kedokteran).30(02).

6. Moorthy RS, Rajeev B, Smith RE, Rao NA. Incidence and management of cataracts in Vogt-Koyanagi-Harada 
syndrome. American journal of ophthalmology. 1994;118(2):197-204.

7. Andjelić S, Hawlina M. Cataractogenesis. Slovenian Medical Journal. 2012;82.

8. Nicula C, Szabo I. Vogt-Koyanagi-Harada syndrome Case report. Romanian journal of ophthalmology. 2016;60(3):181.

9. Quek DT-L, Jap A, Chee SP. Risk factors for poor visual outcome following cataract surgery in Vogt-Koyanagi-Harada disease. British Journal of Ophthalmology. 2011;95(11):1542-6.

10. Skuta GLC, L. B. Vogt-Koyanagi-Harada Syndrome American academy of ophthalmology; 2011. 183-90 p.

11. Meacock W, Spalton D, Bender L, Antcliff R, Heatley C, Stanford M, et al. Steroid prophylaxis in eyes with uveitis undergoing phacoemulsification. British journal of ophthalmology. 2004;88(9):1122-4.

12. Arevalo JF, Lasave AF, Gupta V, Kozak I, Al Harbi MB, Al Rushood AA, et al. Clinical outcomes of patients with VogtKoyanagi-Harada disease over 12 years at a tertiary center. Ocular immunology and inflammation. 2016;24(5):521-9.

13. Perente I, Utine CA, Cakir H, Kaya V, Tutkun IT, Yilmaz OF. Management of ocular complications of Vogt-KoyanagiHarada syndrome. International ophthalmology. 2009;29(1):33-7.

14. Rao NA, Sukavatcharin S, Tsai JH. VogtKoyanagi-Harada disease diagnostic criteria. International ophthalmology. 2007;27(2-3):195-9.

15. O'Keefe GAD, Rao NA. Vogt-KoyanagiHarada disease. survey of ophthalmology. 2017;62(1):1-25.

16. Yang P, Ren Y, Li B, Fang W, Meng Q, Kijlstra A. Clinical characteristics of Vogt-Koyanagi-Harada syndrome in Chinese patients. Ophthalmology. 2007;114(3):606-14. e3. 